\title{
The development of the methodical approach to value business appraisal within the integration policy for industrial enterprises
}

\author{
M. Karelina ${ }^{1, *}$ \\ ${ }^{1}$ Nosov Magnitogorsk State Technical University, Magnitogorsk, Russia
}

\begin{abstract}
At present, a positive trend in the development of corporate integration processes in industrial economics of the Russian Federation is frequently accompanied by a negative dynamics in their efficiency indicators. This causes the necessity for development of an integrated approach to integration transaction valuation using mathematical and statistical methods of research in order to increase the competitiveness of the Russian industry under conditions of the economic sanctions. The paper presents the methodical approach developed to value business appraisal of industrial enterprises based on the integration of profitable, cost-based, sales comparative approaches and the method of real options using weights Fishburne. In this paper, we propose a methodical approach that provides an integrated value appraisal of the target company and preliminary substantiates the expediency of mergers and acquisitions. In addition, this methodical approach is the foundation for high quality and reliable evaluation of the synergistic effect.
\end{abstract}

\section{Introduction}

Mergers and acquisitions taking place in business are aimed at increasing its scope and market share and becoming important factors for increasing the competitiveness under conditions of the economic sanctions against Russia, volatility of foreign exchange markets, and price reduction of raw materials. A technological breakthrough in the field of telecommunications and the deregulation of national markets created an entirely new environment for business dealing [1-2].

At the same time, the complex of problems related to business valuation at mergers and acquisitions has been insufficiently developed. The International Valuation Standards published by the International Valuation Standards Committee as well as guides to the standards issued in 2007 represented the definitions of different types of costs, valuation types, including at the mergers and acquisitions. However, the range of problems under reviewing is insufficient to obey the standard provisions in practice of industrial enterprises.

The development of the merger and acquisition market requires the more serious development of approaches to the integration transaction evaluation in the theory and additional amendments of existing standards. During the study, it was found that there are a number of problems which often take place in practice at evaluating industrial companies but they are usually referred to neither in educational nor in scientific literature:

- there are companies that are difficult to model and evaluate because of specific problems with their reporting;
- there are companies which balance of the structure is expected with significant changes, for example, as a result of share buybacks;

- there are high cyclic companies at which evaluating it is difficult to determine what level of extrapolation should be selected for long-term extrapolation;

- there are companies with a high proportion of intangible assets, often not involving in the balance sheet, what makes difficult to determine the actual return on capital;

- there are fast-growing and highly profitable companies, the main problem in this case is to determine what rates of drawdown of growth indicators, and profitability ratios towards normal levels should be expected.

Thus, there is a need to develop a methodical approach to value business appraisal within the integration policy for industrial enterprises based on the existing Russian and foreign experience with the use of mathematical and statistical methods.

\section{A methodical approach to value enterprise appraisal in merger and acquisition transactions}

Currently, the dynamics of prices for raw materials in Russia, as well as throughout the world, is a special challenge to the established system of pricing for the production of metallurgical companies. Under these circumstances, the Russian steel company announced its decision to purchase one of the coal companies, which in 2008 was included in a government list of strategic companies in Russia. This should allow the creation of a

*Corresponding author: marjyshka@mail.ru 
highly vertically integrated structure and result in an increase in the value of the steel company.

The determination of the value of the coal company by the discounted cash flow method is based on the expectation that the metallurgical company will not be able to pay for this business the sum greater than the present value of future incomes from this business. The mathematical model for value company appraisal by the discounted cash flow method can be presented as [3]:

$$
V^{D C F}=\sum_{i=1}^{n} \frac{F C F F_{i}}{\left(1+r^{C A P M}\right)^{i-0.5}}+\frac{T V}{\left(1+r^{C A P M}\right)^{n}}-D \text {, }
$$

where $\mathrm{FCFF}_{\mathrm{i}}$ is free cash flow to the firm of $i$-th year; $r^{C A P M}$ is the discount rate determined on the base of the capital asset pricing model; $T V$ is terminal value; $D$ is net debt of company.

The capital asset pricing model is based on the analysis of data arrays of the stock market. The discount rate according to the CAPM (Capital Asset Pricing Model) is defined as [4-5]:

$$
r^{C A P M}=r_{f}+\beta\left(r_{m}-r_{f}\right),
$$

where $r_{f}$ is the rate of earnings on risk-free investments; $\beta$ is a beta coefficient, which is a measure of systematic or market risk relating to macroeconomic and political processes; $r_{m}$ is the market average rate of return.

At the appraisal of coal company's value the risk-free rate $r_{f}$ was determined at the level of profitability of the Russian Federation federal loan bonds (the issuer is the Ministry of Finance of the Russian Federation, the general services agent is the Central Bank of the Russian Federation). Then, based on the average profitability of FLB the rate of earnings on risk-free investments is equal to $r_{\mathrm{f}}=10.11 \%$.

The average market rate of return $r_{m}$ is determined on the base of the revenue position on the security market in the sector to which the valued company belongs. Since among all coal companies of the Russian Federation the shares of Southern Kuzbass Coal Company are longestlisted on the stock exchange (RTS since 2003) ordinary income shares of Southern Kuzbass Coal Company were taken as the average market rate of return $r_{m}$. Thus, $r_{m}$ is $16.72 \%$.

The beta coefficient $\beta$ is a measure of systematic (market) risk for the coal companies in developing markets (including Russia) and is equal 0.37. Then, based on expression (2) the following was obtained:

$$
r^{C A P M}=10.11+0.37(16.72-10.11)=12.56 \% .
$$

A cash flow to equity model was chosen as a cash flow model in order to evaluate the coal company by the DCF method. At the same time with efficient management of the company, the term of its life tends to infinity. The terminal value of the project is determined to take into account incomes which business can bring beyond the forecasting period [6-9].

In the present study, the Gordon model was chosen to calculate the company's value in post-forecasting period, according to which the determination of business value is carried out by income capitalization of the first postforecasting year on the capitalization rate, which takes into account the long-term growth rate of cash flows. Then, the terminal value is determined in according to the expression (3):

$$
T V=\frac{F C F F_{(n+1)}}{r^{C A P M}-\xi},
$$

where $\mathrm{FCFF}_{(\mathrm{n}+1)}$ is free cash flow to the firm in the postforecasting period; $\xi$ is long-term (conditionally permanent) growth rates of cash flow in the residual period.

Net cash flow on capital in the post-forecasting period is equal to 194.67 million USD. In accordance with the market conditions of coking coals, experts from Economic Directorate of the Ural Metallurgical Company estimated long-term rates of cash flow growth in the residual period at the level $\xi=0,5 \%$. Therefore, terminal value is equal to:

$$
T V=\frac{194.67}{0.1256-0.005}=1614.19 m \ln U S D .
$$

Net debt of the coal company at the time of the integration transaction was $\mathrm{D}=526$ million USD. At that time the coal company value according to the method of discounted cash flows was:

$$
\begin{aligned}
V^{D C F}=822.86+(1614.19 * 0.2025)-526 & \approx \\
& \approx 623.65 \mathrm{~m} \ln U S D .
\end{aligned}
$$

The cost approach is based on the principle of substitution: the company's cost is no more than charges for replacing of all its integrated parts. The basic formula of the cost approach is as follows [10]:

$$
\text { The company's value }=\text { Assets }- \text { Liabilities. }
$$

The method of net assets under the cost approach is based on a balance adjustment in connection with the fact that the book value of assets and liabilities of the company does not always correspond to their real value. Under business valuation when using the method of net assets (Order of the Ministry of Finance of the Russian Federation and Federal Securities Market Commission of January 29, 2003 On approval of the Procedure of Appraisal of Net Assets of Joint Stock Companies No $10 \mathrm{n}, 03-6 / \mathrm{pz}$ ) the traditional balance of the enterprise is replaced by the adjusted balance, in which all the assets and liabilities are shown on the market or any other suitable current value. Then, the value of the coal company in accordance with the method of net assets is $V^{N A} \approx 227.45 \mathrm{mln} U S D$.

A comparative approach is a combination of methods for value company appraisal, based on the comparison of the valued object with its analogues in respect of which there is information on prices. In Russia, two methods of the comparative approach: capital market and transaction market are commonly used for company valuation. The transaction method is based on a direct comparison of the valued enterprise with analogous ones in respect of 
which the price of a controlling interest or the company as a whole is known.

The use of valuation multipliers within the transaction method is based on the assumption that analogue companies have a sufficiently close relationship between the price and the most important financial indicators. Thus, the price of the enterprise can be determined by multiplying finance indicator by the corresponding multiplier.

With a relatively small sample of analogue companies, there is a problem - the error of statistical calculations. At the same time when determining any multiplier according to its sampling values (for individual analogue companies), one can assume that these values are normally distributed [11-14].

Then, when determining the required number of analogue companies $n$, in order to a multiplier $M$ with a given probability $\alpha$ lies within a certain range $\left(\mu\left(M_{i}\right)-\beta \mu\left(M_{i}\right), \mu\left(M_{i}\right)+\beta \mu\left(M_{i}\right)\right)$, the problem was solved on finding the centre of the normal distribution with a known dispersion [15-18]. Thus, for relationship between dispersion and mathematical expectation equal to 0.15 , and the probability of $\alpha$ equal to $95 \%$ entering the range $\mu\left(M_{i}\right) \pm 13 \%$, the sample size of analogue companies must be equal to 5 .

A key point in searching analogue companies is to find information on transactions with blocks of shares. Since the information on mergers and acquisitions without the participation of the state is enclosed, the data on the sale of large blocks of shares is generally relative to the auctions for privatization held by the state. We present the data on potential analogue companies for the coal company under consideration in Table 1.

Despite the fact that many researchers consider multipliers calculated on profits the best accurate valuation, the author of the study had primarily denied them. This is because under present conditions Russian companies try to overvalue the cost of their production in every possible way in order to minimize income tax.

Table 1. The data on the auctions for the sale of coal company shares.

\begin{tabular}{|c|c|c|c|}
\hline $\begin{array}{c}\text { Name of the } \\
\text { company }\end{array}$ & $\begin{array}{c}\text { Block of } \\
\text { shares, } \\
\text { \%o }\end{array}$ & $\begin{array}{c}\text { Selling } \\
\text { price of a } \\
\text { block (mln } \\
\text { RUB) }\end{array}$ & $\begin{array}{c}\text { Estimated } \\
\text { value of } \\
\mathbf{1 0 0 \%} \text { of a } \\
\text { block } \\
\text { (mln } \\
\text { USD) }\end{array}$ \\
\hline Southern Kuzbass & $26 \%$ & 55.14 & 7.07 \\
\hline Kuzbassrazrezugol & $26 \%$ & 166.51 & 21.35 \\
\hline $\begin{array}{c}\text { Krasnoyarsk Coal } \\
\text { Company }\end{array}$ & $76 \%$ & 339.41 & 14.89 \\
\hline $\begin{array}{c}\text { Mezhdurechensk } \\
\text { Coal Company }\end{array}$ & $100 \%$ & 120.13 & 4.00 \\
\hline Khakasugol & $39 \%$ & 23.43 & 2.00 \\
\hline
\end{tabular}

The use of the multiplier on the book value of equity in cost calculation of the coal company also seems inappropriate since the book value of Russian companies too often deviates significantly from its market value. Thus, the relationship "company's price - income" is a widely used multiplier. Income indicators are subject to the least misstatement among all the financial indicators of the Russian companies, however, this multiplier should also be used with great caution since at different proportions of the debt to equity capital ratio its use may result in significant misstatements. Since at selection of analogue companies the debt to equity capital ratio was taken as a criterion for the comparability of companies, we selected this multiplier for the study.

Considering that the coal company is a company in the raw material sector, we also used the multipliers based on the characteristics of resource stocks for its valuation:

- company's value - coal production;

- company's value - prospected coal reserves.

The multiplier values calculated are shown in Table 2. In this case, when calculating the multipliers we took financial and natural indicators for the last fiscal year.

Table 2. The multiplier values for value coal company business appraisal in analogue companies.

\begin{tabular}{|c|c|c|c|}
\hline \multirow{2}{*}{$\begin{array}{c}\text { Name of the } \\
\text { company }\end{array}$} & $\begin{array}{c}\text { Multipliers } \\
\text { Company's } \\
\text { value - } \\
\text { income }\end{array}$ & $\begin{array}{c}\text { Company's } \\
\text { value - } \\
\text { mining }\end{array}$ & $\begin{array}{c}\text { Company's } \\
\text { value- } \\
\text { prospected } \\
\text { coal } \\
\text { reserves }\end{array}$ \\
\hline $\begin{array}{c}\text { Southern } \\
\text { Kuzbass }\end{array}$ & 0.87 & 0.73 & 4.26 \\
\hline $\begin{array}{c}\text { Kuzbassrazrez } \\
\text { ugol }\end{array}$ & 0.93 & 0.80 & 4.81 \\
\hline $\begin{array}{c}\text { Krasnoyarsk } \\
\text { Coal } \\
\text { Company }\end{array}$ & 0.95 & 0.63 & 4.78 \\
\hline $\begin{array}{c}\text { Mezhdu } \\
\text { rechensk } \\
\text { Coal } \\
\text { Company }\end{array}$ & 0.73 & 0.74 & 5.55 \\
\hline Khakasugol & 0.78 & 0.80 & 4.57 \\
\hline $\begin{array}{c}\text { Average } \\
\text { value: }\end{array}$ & $\mathbf{0 . 8 5}$ & $\mathbf{0 . 7 4}$ & $\mathbf{4 . 7 9}$ \\
\hline
\end{tabular}

We calculated the price of the coal company on the base of the multiplier values (see Table 3 ).

The use of different multipliers gives various options for the company's value. So the average price of the coal company with the use of the multiplier "the company's value - income" amounted to 422.88 million USD; with the use of the multiplier "the company's value - coal production" - 451.92 million USD; with the use of the multiplier "the company's value - prospected coal reserves" - to 511.57 million USD. The choice of the result is based on giving a percentage weight to each cost option. Assuming that all three multipliers are equal in importance the value of the coal company results in $V^{T} \approx 463.12$ million USD.

At present, increased significance of the latest methods of business valuation allows them to be used in practice both for valuation by foreign investors and for making incompany decisions that are more considered and focus on cost management in the long term. Among such methods is a method of real options. 
Table 3. Calculation of the coal company's value using multipliers.

\begin{tabular}{|c|c|c|c|c|}
\hline \multicolumn{2}{|c|}{} & \multicolumn{2}{|c|}{$\begin{array}{c}\text { The } \\
\text { Coal company } \\
\text { performance } \\
\text { indicator, mIn USD } \\
\text { average } \\
\text { sales } \\
\text { price of } \\
\text { coal } \\
\text { company, } \\
\text { mIn USD }\end{array}$} \\
\hline $\begin{array}{c}\text { gross } \\
\text { incomes }\end{array}$ & 501.03 & $\begin{array}{c}\text { Multiplier value } \\
\text { company's } \\
\text { value- } \\
\text { income }\end{array}$ & 0.85 & 425.88 \\
\hline $\begin{array}{c}\text { coal } \\
\text { mining } \\
\text { value - } \\
\text { mining }\end{array}$ & 610.70 & 0.74 & 451.92 \\
\hline $\begin{array}{c}\text { company's } \\
\text { prospected } \\
\text { coal } \\
\text { reserves }\end{array}$ & 106.80 & $\begin{array}{c}\text { prospected } \\
\text { coal reserves }\end{array}$ & 4.79 & 511.57 \\
\hline
\end{tabular}

The most important feature of an optional method of business valuation is its ability to take into account the rapidly changing economic environment in which the company acts. At the same time, a ROV-method has not yet been recognized in full; limits and possibilities of its application are still the point for discussion. Nevertheless, experts in the field of evaluation pay attention to this method in different countries that results in conclusion that its research is an urgent task and for Russia.

The Ohlson model and Black-Scholes model are the best-known models for determining the company's value based on the method of real options. The peculiarity of the Ohlson model is the use of abnormal incomes. The concept of abnormal incomes is based on the following assumptions. Let $b_{t}$ be the book value of the company at time $t$ and $d_{t}$ - dividends paid during the year in the period from $t-1$ to $t$ [19-20]. Then the total income of the shareholder (denoted as $\mathrm{x}_{\mathrm{t}}$ ) for the period $\mathrm{t}$ is the dividend plus the addition of book value of the company:

$$
x_{t}=b_{t}-b_{t-1}+d .
$$

At the beginning of the period under review, that is, at time t-1 the company owner by the end of the time interval from $t-1$ to $t$ expects to get income equal to $r b_{t}-1$. This is a consequence of the determination of the discount rate $r$. This value, that is, the income based on the discount rate is called average income:

$$
x_{\text {норм }}=r b_{t-1} \text {. }
$$

Abnormal income is the discrepancy an investor receives between the actual return on capital and the expected return, that is, the return based on the discount rate:

$$
x_{t}^{a}=x_{t}-r b_{t-1} .
$$

The most common way to use the value of abnormal incomes for obtaining the company's cost value is the capitalization of abnormal income and the addition of this value to the company's cost resulted from the cost of its assets. This capitalization of abnormal income is carried out using the conventional capitalization rate, which is equal to the difference between the discount rate and the average rate of income growth.

The model described is the Edwards-Bell-Olson model (EBO). In the light of this, the company's cost in the Edwards-Bell-Olson model will be equal to:

$$
V^{E B O}=b_{t}+\frac{x_{t}}{r-g} .
$$

where $V^{E B O}$ is the company's cost in the EdwardsBell-Olson model; $g$ is the expected average annual growth rate.

In the Olson model, the dynamics of abnormal incomes was proposed in contrast to their invariance condition, as in the Edwards-Bell-Olson model. In accordance with this, the economic meaning of the term "abnormal incomes" has been changed.

According to the Olson model, the company's value at time $\mathrm{t}$ is equal to the initial "accounting" value of the company plus the sum of discounted abnormal incomes:

$$
V_{t}^{O L}=b_{0}+\sum_{i=1}^{n} \frac{E_{t}\left[x_{t+i}\right]}{(1+r)^{i}} .
$$

where $E_{t}\left[x_{t+i}\right]$ is a predicted value of abnormal incomes.

Thus, in order to find the final cost value it is necessary to set an explicit expression for the predicted abnormal income values. Olson proposed the following time dynamics of the abnormal income behaviour:

$$
\begin{aligned}
& x_{t+1}^{a}=\omega x_{t}^{a}+v_{t}+\varepsilon_{1, t+1} \\
& v_{t+1}=\gamma v_{t}+\varepsilon_{2, t+1}
\end{aligned} .
$$

where $\omega$ is the given empirical value indicating which part of the abnormal income in the previous year remains in the current year; $v$ is the value characterizing the difference between the expected and actual value of abnormal incomes; $\gamma$ is the given empirical value indicating which part $v$ of the last year is preserved in the current year $(\gamma<0)$; $\varepsilon$ is the normally distributed error with zero mean (considered noise, not related to the speed of the abnormal-income decrease).

Expression (9) shows that abnormal incomes with time tend to zero magnitude. This means that, in comparison with other companies the valued company eventually loses its original "advantages" relating to the situation on the market and its income tends to the determined average market rate of return, that is, to a discount rate $r$.

Substituting the expression for abnormal incomes (9) in the formula for the final cost value (8) we obtain the desired result:

$$
V_{t}^{O L}=b_{t}+a_{1} x_{t}^{a}+a_{2} v_{t},
$$


where

$$
\begin{gathered}
a_{1}=\frac{\omega}{(1+r-\omega)} ; \\
a_{2}=\frac{1+r}{(1+r-\omega)(1+r-\gamma)} ; \\
v_{t}=\gamma\left(x_{t}^{a}-\omega x_{t-1}^{a}\right) .
\end{gathered}
$$

The Committee for appraisal activities of the Chamber of Commerce and Industry of the Russian Federation recommends taking for $\omega$ and $\gamma$ the values equal to 0.62 and 0.32 . Then $\mathrm{a}_{1}$ is equal $1.226 ; \mathrm{a}_{2}$ is equal 2.764; $\quad v_{t}=366821.98$ thousands RUB. Substituting the values obtained in (10) the coal company's cost value results in $V^{O L} \approx 348.80 \mathrm{mln} U S D$.

According to the Black-Scholes model, the company's cost value is represented as the call option value, consisting of the company's assets and liabilities. At the same time, the Black-Scholes model is considered as the "ultimate" case of the binomial model. The initial premise of the model is the normal probability distribution. Based on this premise the basic formula of the model is made (in relation to a European call option on the right to purchase the asset):

$$
V^{B-S}=S^{*} N\left(d_{1}\right)-X^{*} e^{-r_{f} t} * N\left(d_{2}\right),
$$

where $V^{B-S}$ is the value of the appraised company; $\mathrm{S}$ is the value of a company's asset; $\mathrm{X}$ is the value of liabilities; $r_{f}$ is the risk-free rate; $t$ is duration of company's debt;

$\mathrm{N}\left(\mathrm{d}_{1}\right)$ and $\mathrm{N}\left(\mathrm{d}_{2}\right)$ are cumulative normal probabilities of density distribution function, where:

$$
\begin{aligned}
& d_{1}=\frac{\ln \left(\frac{S}{X}\right)+\left(r_{f}+\frac{\sigma^{2}}{2}\right) t}{v \sqrt{t}} \\
& d_{2}=\frac{\ln \left(\frac{S}{X}\right)+\left(r_{f}-\frac{\sigma^{2}}{2}\right) t}{v \sqrt{t}}
\end{aligned}
$$

It should be noted that the company's value calculated on the Black-Scholes model decreases with the increased parameter $\mathrm{X}$ and increases with the growth of other parameters. Also $d_{1}>d_{2}$, and as a consequence $\mathrm{N}\left(\mathrm{d}_{1}\right)>\mathrm{N}\left(\mathrm{d}_{2}\right)$.

Initial data for the calculation of the coal company's cost in accordance with the Black-Scholes model is presented in Table 4. The value of assets was determined in accordance with the approved order of the Ministry of Finance of the Russian Federation of 05.08.1996, No72 and of the Federal Commission on Securities Market of 05.08.1996, No149, that is, according to the results of the cost assessment method. The nominal value of liabilities was determined in the same way.
Table 4. Initial data for calculation of the coal company's value

\begin{tabular}{|c|c|}
\hline Initial data & Value \\
\hline 1. Asset value $S$, thousand RUB & 20146402 \\
\hline $\begin{array}{c}\text { 2. Nominal value of liabilities X, } \\
\text { thousand RUB }\end{array}$ & 12989591 \\
\hline 3. Duration of company's debt, year & 2.97 \\
\hline 4. Risk-free interest rate $\mathrm{r}_{\mathrm{f}}, \%$ & 10.11 \\
\hline 5. Variation of company's value, $\%$ & 43.57 \\
\hline
\end{tabular}

The substitution of the initial data in (11) and (12) results in the value of the coal company equal to $V^{B-S} \approx 379.48 m \ln U S D$ in accordance to the BlackScholes model.

Table 5 shows the calculated value of the coal company in accordance with the income approach (a discounted cash flow method), the cost approach (a net assets method), the comparative approach (a transaction method) and the method of real options (the Ohlson model and the BlackScholes model).

Table 5 illustrates that the maximum value company appraisal was determined by the discounted cash flow method ( $V^{D C F} \approx 623.65 \mathrm{mln} U S D$ ), and the minimum one was determined by the net assets method $\left(V^{N A} \approx 227.45 \mathrm{mln} U S D\right)$.

Table 5. The coal company's value based on various methods.

\begin{tabular}{|c|c|}
\hline Method & Company's value \\
\hline 1. DCF method & $V^{D C F} \approx 623.65 m \ln U S D$ \\
\hline 2. Net asset method & $V^{N A} \approx 227.45 m \ln U S D$ \\
\hline $\begin{array}{c}\text { 3. Transaction } \\
\text { method }\end{array}$ & $V^{T} \approx 463.12 \mathrm{~m} \ln U S D$ \\
\hline 4. The Ohlson model & $V^{O L} \approx 348.80 \mathrm{mln}$ USD \\
\hline $\begin{array}{c}\text { 5. The Black-Scholes } \\
\text { model }\end{array}$ & $V^{B-S} \approx 379.48 \mathrm{~m} \ln$ USD \\
\hline
\end{tabular}

Figure 1 represents a model of integrated value business appraisal in merger and acquisition transactions. At the same time, for the integrated business valuation it is necessary to determine the weighting coefficient for every appraisal value of the valued company. For this, we suggest to place all values in decreasing order of their importance and to determine the significance of the $\mathrm{i}$-th value according to the Fishburne rule [21].

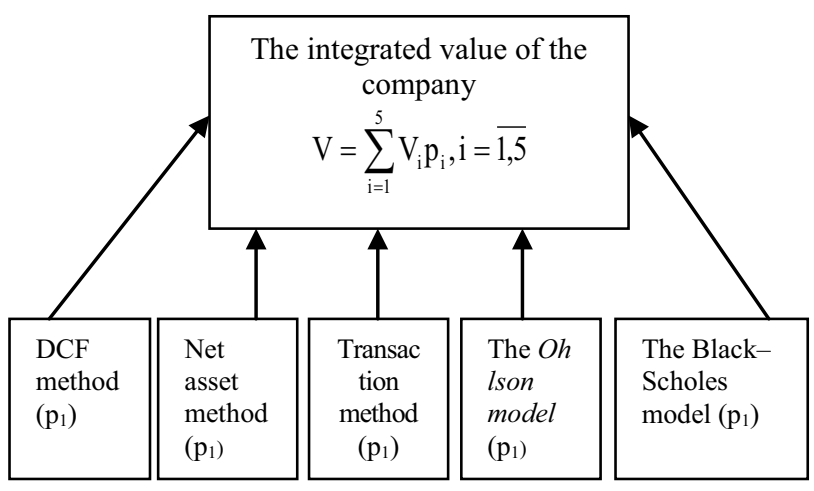

Fig. 1. The model of the integral value company appraisal in merger and acquisition transactions. 
Let us consider the order of weights Fishburne construction. The system of weights reducing in accordance to the arithmetic progression rule best meets the system of decreasing preference of $n$ alternatives:

$$
p_{i}=\frac{2(n-i+1)}{(n+1) n}, i=\overline{1, n} .
$$

and a set of equal weights best meets the system of indifferent to each other alternatives:

$$
p_{i}=n^{-1}, i=\overline{1, n} \text {. }
$$

To determine a set of Fishburne weights for the mixed system of preferences when, along with preferences, the system includes the relationship of indifference, it is necessary to determine the numerators $r_{i}$ of rational fractions according to the recursive scheme:

$$
r_{i-1}=\left\{\begin{array}{l}
r_{i}, F_{i-1} \approx F_{i} \\
r_{i}+1, F_{i-1} \succ F_{i}
\end{array} \cdot r_{n}=1, i=n \ldots 2 .\right.
$$

Then the sum of the numerators obtained is the common denominator of fractions Fishburne $K=\sum_{i=1}^{n} r_{i}$ and:

$$
p_{i}=\frac{r_{i}}{K}
$$

On the base of considerations of generally accepted appraisal practices and practical experience of business appraisers of International Academy of Appraisal and Consulting and Committee for appraisal activities of the Chamber of Commerce and Industry of the Russian Federation:

$$
V^{D C F} \succ V^{T} \succ V^{O L} \approx V^{B-S} \succ V^{N A} .
$$

Then the weights Fishburne for the integrated value business appraisal of the coal company takes the following form (see Table 6).

The integrated value appraisal of the coal company was calculated based on Table 6 $V_{\text {инт. }}=463,99 \mathrm{mln}$ USD.

Table 6. Weights fishburne for value appraisal of the coal company.

\begin{tabular}{|c|c|c|c|c|c|}
\hline & $V^{N A}$ & $V^{B-S}$ & $V^{O L}$ & $V^{T}$ & $V^{D C F}$ \\
\hline $\mathrm{p}_{\mathrm{i}}$ & $\frac{1}{12}$ & $\frac{1}{6}$ & $\frac{1}{6}$ & $\frac{1}{4}$ & $\frac{1}{3}$ \\
\hline
\end{tabular}

In accordance with the traditional three levels of the company's value model (the level of control, the level of liquid minority blocks of shares and the level of unliquid minority blocks of shares) at the acquisition of the coal company buyout in addition a control premium arises.

In many areas of business appraisal in Russia, the empirical data on the base of which it is possible to calculate the size of the control premium is closed and not available in many cases. Therefore, as an estimate of the control premium we took the data presented by Mergerstat Review. In compliance with that data, the premium for the acquisition of controlling stake shares of public companies in the USA in 2005-2008 on average fluctuated from $33 \%$ to $40 \%$. Then the final integrated value appraisal of the coal company on average fluctuates from $617.11 \mathrm{mln}$ USD to 649.59 mln USD.

\section{Conclusion}

The statistical approach proposed to value business appraisal within the integration policy for industrial enterprises provides an integrated value business appraisal, forms a preliminary justification of expediency of mergers and acquisitions and is a foundation for high-quality and reliable valuation of the integration transaction, which allows one to make a considered investment decision. All these will contribute to the increase in the competitiveness and the stable industry development in Russia.

The work is performed under the grant of the President of the Russian Federation for state support of young Russian scientists - PhDs (MK-5339.2016.6)

\section{References}

1. M. Polikarpova, Vestnik of Nosov Magnitogorsk State Technical University, 3, 95-102 (2011)

2. M. Polikarpova, Risk analysis and the effectiveness of mergers and acquisitions of Russian companies (Moscow, NPO MAX Group, 2012)

3. A.G. Gryaznova. M.A. Fedotova, Business valuation textbook. second edition (Moscow, 2009)

4. D. Fishmen, Sh. Pratt, K. Griffit, K. Uilson, Guide to Business Valuations (KwintoConsulting, Moscow, 2008)

5. V.Popkov, E. Yevstafyeva, Business Valuation. Diagrams and tables: Textbook (Piter, Saint Petersburg, 2007)

6. A. Damodaran, Valuation of assets (Potpourri, Moscow, 2011)

7. N. Chebotarev, Valuation of Enterprise (Dashkov and Co., Moscow, 2014)

8. O. Maslenkova, Valuation of Enterprise (Business) (KnoRus, Moscow, 2011) 
9. F. Evans, D. Bishop, Assessment of companies in mergers and acquisitions: the creation of value in private companies (Alpina Pablishar, Moscow, 2004)

10. S. Valyuh, B. Gadzhimet, E. Hours, Energy - XXI century, 3(65), 70-79 (2007)

11. S. Aivazian, I. Enyukov, L. Meshalkin, Applied Statistics. Dependency Research (Finance and Statistics, Moscow, 1985)

12. S. Aivazian, V. Mkhitaryan, Applied Statistics and Econometrics fundamentals. Volume 1: Theory of Probability and Statistics, specialty Applied (UNITY-DANA, Moscow, 2001)

13. I. Eliseeva, Statistics (Yurayt Publishing, Moscow, 2012)

14. V. Gmurman, Theory of Probability and Mathematical Statistics (Higher School, Moscow, 1977)

15. N. Kremer, Probability theory and mathematical statistics (Unity, Moscow, 2003)
16. V. Mkhitarian, Data analysis (Yurayt Publishing, Moscow, 2016)

17. Y. Sazhin, N. Rodionov, Statistical methods for research on the socio-economic processes (Saransk, Publisher Mordovia University, 1998)

18. E. Khrustalev, O. Khrustalev, The economic analysis: theory and practice, 45, 11-16 (2011)

19. Guidelines on the business valuation using the Ohlson model and the Black-Scholes model (International Academy of Valuation and Consulting, Moscow, 2010)

20. I. Ansoff, The new corporate strategy (Piterka, St. Petersburg, 1999)

21. P. Fishburn, Utility theory for decision (Science, Moscow, 1978) 